\title{
Some Biological Aspects of Neon Flying Squid Ommastrephes bartrami Caught by Japanese Squid Gillnetters in the North Pacific
}

\author{
Mamoru Murata, ${ }^{* 1}$ Yoshikazu Nakamura, ${ }^{* 1}$ Seigo Kubota, ${ }^{* 2}$ \\ Toshio Hashiba, ${ }^{* 2}$ and Hirotsune Yamaguchi*2 \\ (Received March 9, 1988)
}

\begin{abstract}
In order to elucidate the stock structure and growth of neon flying squid, seasonal variations in dorsal mantle length, sex ratio, gonad weight and degree of sexual maturity of this species are presented here on the basis of the results of biological measurements of the samples taken by squid gillnetters during June and December in 1983-1985. The majority of the sampled squid were immature and not copulated females, while the proportion of males in number was only $2.4 \%$ in the 3 -year average, and about half of the males were semi-mature $(11 \%)$ or mature $(36 \%)$. The principal modal mantle length in females shifted from $37 \mathrm{~cm}$ level in June to $45 \mathrm{~cm}$ level in September, then backed again to a smaller modal size within the range of $35-41 \mathrm{~cm}$ in October-November. The ovary weights showed a general tendency to gradually increase between June and August, but this was followed by an abrupt decrease in September. Judging from these results, it is presumed that Japanese squid squid gillnetters mainly catch "extra-large sized" group of neon fiying squid in JuneSeptember and "large sized" one in October-December, selectively out of four different size groups in the northern North Pacific.
\end{abstract}

Japan's annual catches of neon flying squid Ommastrephes bartrami ranged from 130,000 to 230,000 tonnes between 1982 and 1986, and approximately $70-80 \%$ of the catches were taken by the squid gillnet fishery. ${ }^{1)}$ The squid gillnet fishery was commeneced in 1978, and from 1979 onward, the fishing grounds extended over a very broad area in the northern North Pacific between long. $170^{\circ} \mathrm{E}$ and $145^{\circ} \mathrm{W}$. Most of the catches by squid gillnetters are quickly processed on board: the mantle, head and arms, and fin of the squid are separately frozen after removal of the viscera. The fishing trips of these gillnetters are made for a month at the shortest and for 5 months at the longest.

Because of such operational conditions on these gillnetters, it is very difficult to obtain squid samples for biological studies. Consequently, no detailed information is yet available on the growth and sexual maturity of neon flying squid, target species of gillnetters in the North Pacific.

According to the previous reports, ${ }^{2-5)}$ the catches of neon flying squid in the North Pacific consist of 2 to 4 different size groups. Moreover, since neon flying squid taken by the gillnetters are clearly larger in size than those taken by the squid jigging vessels during the same period, it appears that the gillnetters are harvesting the group (or groups) composed of larger individuals. ${ }^{4,5}$ However, it is pointed out that the squid caught by gillnetters tend to decrease in size after September. ${ }^{5}$ Furthermore, some fishermen are of the opinion that squids taken in the eastern part of the fishing ground tend to be larger than those taken in the waters farther to the west. In this way, there are still many unknowns with regard to the stock structure of neon flying squid under considereation.

As a part of the researches on the stock structure and growth of neon flying squid in the North Pacific, the authors have carried out various biological measurements of samples obtained from cooperating squid gillnetters. In this report, seasonal variations in mantle length, sex ratio, gonad weight, and degree of sexual maturity of neon flying squid were presented on the basis of the results of biological measurements made from

*1 Hokkaido Regional Fisheries Research Laboratory, Katsurakoi, Kushiro, Hokkaido 085, Japan (村田 守, 中村好和: 北海道区水産研究所).

*2 Tohoku Regional Fisheries Research Laboratory, Hachinohe Branch, Same, Hachinohe, Aomori 031,

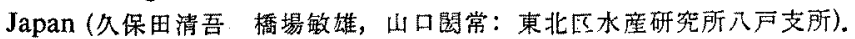


1983 to 1985.

\section{Materials and Methods}

The samples were obtained during the 1983-85 fishing seasons, June-December every year, from a total of 8 cooperating squid gillnetters: 2 vessels of 99 and 499 GT in 1983, 3 vessels of 224, 349 and 396 GT in each of 1984 and 1985. From the squid catch by each vessel, some 10 to 20 specimens were sampled at random 10 days apart, and frozen for subsequent delivery to the laboratory.

Of the gillnets used by these cooperating vessels, the most common ones were of mesh sizes between 114 and $120 \mathrm{~mm}$, which were also the principal nets generally used by the Japanese squid gillnet fishery. Judging from the fishing gear and method used, it is believed that most of the squid were caught at night in the surface layer at depths of less than $10 \mathrm{~m}$.

A total of 1,865 specimens were measured during the period from 1983 to $1985: 458$ squids in 1983, 652 in 1984 and 755 in 1985, which were obtained from 155 different samples (Table 1). The majority of samples were obtained from a very broad area bounded by lat. $36^{\circ} \mathrm{N}$ and $46^{\circ} \mathrm{N}$, and long. $170^{\circ} \mathrm{E}$ and $145^{\circ} \mathrm{W}$ in the northern North Pacific. The sampling area tended to shift northward in June-September and southward in OctoberDecember (Fig. 1).

The mantle lengths of the samples obtained in the same month, varied greatly at times with vessels as well as with areas (Murata, unpublished). In this study, however, we have compiled and analyzed the available data on a monthly basis.

Biological observations included such the usual items as dorsal mantle length (mantle length in short), sex ratio (number of male/number of female), body weight, gonad weight, degree of sexual maturity, etc. The degree of sexual maturity in males was categorized as "mature" if fully developed spermatophores were present in the spermatophore sac, "semi-mature" if the spermaduct appeared whitish, and "immature" in the remaining cases. On the other hand, females were classified as "mature" if amber-colored, fully developed eggs were present in the oviduct, and "immature" in all other cases.

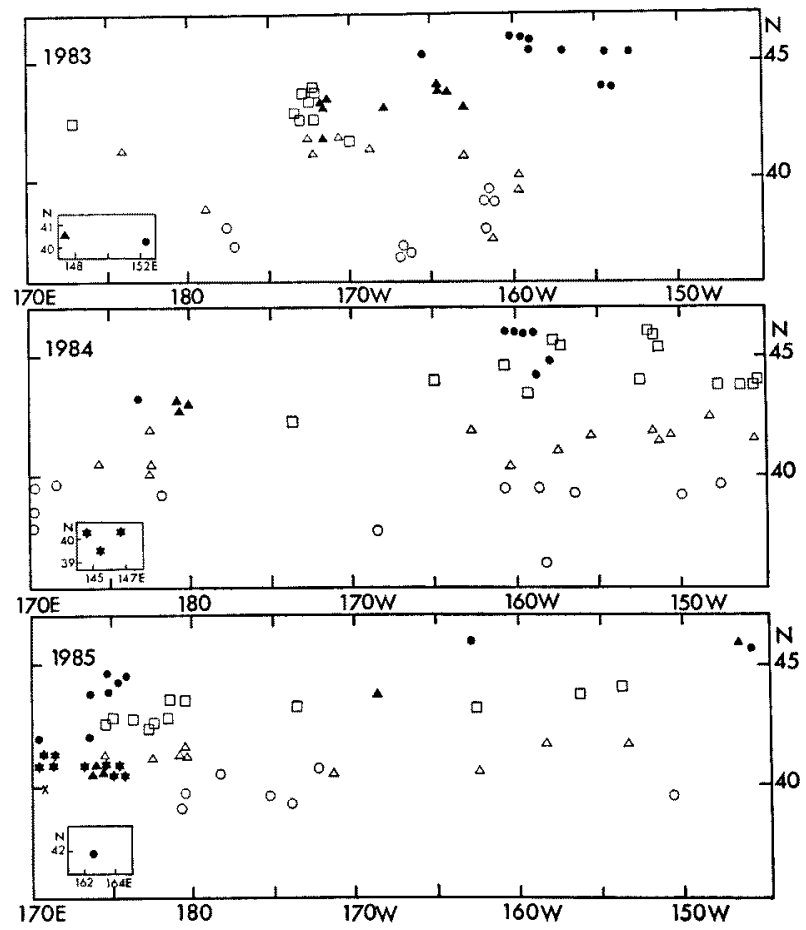

Fig. 1. Locations of sampling neon flying squid caught by squid gillnetters in 1983-1985.

$\checkmark$ June, $\triangle$ July, $\square$ Aug., - Sep., $\wedge$ Oct., $\star$ Nov., $\times$ Dec. 
Table 1. Numbers of samples (S) and individuals (N) measured, and means (M) and standard deviations (SD) of dorsal mantle length, of neon flying squid caught by squid gillnetters in the northern North Pacific

\begin{tabular}{|c|c|c|c|c|c|c|c|c|c|c|c|c|c|c|c|c|c|}
\hline & \multirow[b]{2}{*}{ Sex } & \multicolumn{4}{|c|}{1984} & \multicolumn{4}{|c|}{1984} & \multicolumn{4}{|c|}{1985} & \multicolumn{4}{|c|}{ Total } \\
\hline & & $\mathbf{S}$ & $\mathbf{N}$ & $\underset{(\mathrm{cm})}{\mathrm{M}}$ & $\begin{array}{l}\mathrm{SD} \\
(\mathrm{cm})\end{array}$ & $S$ & $\mathbf{N}$ & $\mathbf{M}$ & SD & $\mathbf{S}$ & $\mathrm{N}$ & $\mathbf{M}$ & SD & S & $\mathbf{N}$ & M & $\mathrm{SD}$ \\
\hline June & $\begin{array}{l}\mathrm{F} \\
\mathrm{M}\end{array}$ & 9 & $\begin{array}{r}96 \\
0\end{array}$ & $\begin{array}{c}38.70 \\
-\end{array}$ & 2.89 & 12 & $\begin{array}{r}155 \\
0\end{array}$ & $\begin{array}{c}39.29 \\
-\end{array}$ & 2.68 & 7 & $\begin{array}{r}89 \\
0\end{array}$ & $\begin{array}{c}41.35 \\
-\end{array}$ & 3.24 & 28 & $\begin{array}{r}340 \\
0\end{array}$ & $\begin{array}{c}39.40 \\
-\end{array}$ & 2.95 \\
\hline July & $\begin{array}{l}\mathrm{F} \\
\mathrm{M}\end{array}$ & & $\begin{array}{r}99 \\
0\end{array}$ & $\begin{array}{c}40.74 \\
-\end{array}$ & 2.64 & 13 & $\begin{array}{r}162 \\
0\end{array}$ & $\begin{array}{c}41.98 \\
-\end{array}$ & $\stackrel{2.93}{-}$ & 10 & $\begin{array}{r}162 \\
0\end{array}$ & $\begin{array}{c}39.48 \\
-\end{array}$ & $\begin{array}{c}2.93 \\
-\end{array}$ & 33 & $\begin{array}{r}423 \\
0\end{array}$ & $\begin{array}{c}40.79 \\
-\end{array}$ & $\underline{3.06}$ \\
\hline Aug. & $\begin{array}{l}\mathrm{F} \\
\mathrm{M}\end{array}$ & 9 & $\begin{array}{r}74 \\
0\end{array}$ & $\begin{array}{c}41.74 \\
-\end{array}$ & $\begin{array}{c}3.14 \\
-\end{array}$ & 14 & $\begin{array}{r}179 \\
7\end{array}$ & $\begin{array}{l}41.05 \\
30.05\end{array}$ & $\begin{array}{l}3.96 \\
3.00\end{array}$ & 12 & $\begin{array}{r}177 \\
1\end{array}$ & $\begin{array}{l}40.48 \\
34.50\end{array}$ & 4.05 & 35 & $\begin{array}{r}430 \\
8\end{array}$ & $\begin{array}{l}40.93 \\
31.00\end{array}$ & $\begin{array}{l}3.89 \\
3.12\end{array}$ \\
\hline Sep. & $\begin{array}{l}\mathrm{F} \\
\mathrm{M}\end{array}$ & 10 & $\begin{array}{r}74 \\
0\end{array}$ & $\begin{array}{c}42.80 \\
-\end{array}$ & $\begin{array}{c}4.14 \\
-\end{array}$ & 7 & $\begin{array}{r}86 \\
0\end{array}$ & $\begin{array}{c}41.41 \\
-\end{array}$ & $\underline{5.21}$ & 10 & $\begin{array}{r}119 \\
0\end{array}$ & $\begin{array}{l}36.70 \\
30.75\end{array}$ & $\begin{array}{l}4.48 \\
1.04\end{array}$ & 27 & $\begin{array}{r}279 \\
8\end{array}$ & $\begin{array}{l}39.76 \\
29.75\end{array}$ & $\begin{array}{l}5.35 \\
1.04\end{array}$ \\
\hline Oct. & $\begin{array}{l}\mathrm{F} \\
\mathrm{M}\end{array}$ & 10 & $\begin{array}{l}84 \\
11\end{array}$ & $\begin{array}{l}40.01 \\
32.31\end{array}$ & $\begin{array}{l}5.57 \\
2.32\end{array}$ & 3 & $\begin{array}{r}30 \\
0\end{array}$ & $\begin{array}{c}38.80 \\
-\end{array}$ & $\underline{3.24}$ & 5 & $\begin{array}{r}67 \\
0\end{array}$ & $\begin{array}{c}39.20 \\
-\end{array}$ & 5.17 & 18 & $\begin{array}{r}181 \\
11\end{array}$ & $\begin{array}{l}39.51 \\
32.31\end{array}$ & $\begin{array}{l}5.10 \\
2.32\end{array}$ \\
\hline Nov. & $\begin{array}{l}\mathrm{F} \\
\mathrm{M}\end{array}$ & 1 & $\begin{array}{r}19 \\
1\end{array}$ & $\begin{array}{l}38.86 \\
35.50\end{array}$ & 2.29 & 3 & $\begin{array}{l}18 \\
15\end{array}$ & $\begin{array}{l}36.89 \\
33.96\end{array}$ & $\begin{array}{l}3.84 \\
1.55\end{array}$ & 9 & $\begin{array}{r}120 \\
2\end{array}$ & $\begin{array}{l}38.06 \\
34.50\end{array}$ & 2.64 & 13 & $\begin{array}{r}157 \\
18\end{array}$ & $\begin{array}{l}38.07 \\
34.11\end{array}$ & $\begin{array}{l}2.77 \\
1.46\end{array}$ \\
\hline Dec. & $\begin{array}{l}\mathbf{F} \\
\mathbf{M}\end{array}$ & 0 & - & - & - & 0 & - & - & - & 1 & $\begin{array}{r}10 \\
0\end{array}$ & $\begin{array}{c}39.80 \\
-\end{array}$ & 2.50 & 1 & $\begin{array}{r}10 \\
0\end{array}$ & $\begin{array}{c}39.80 \\
-\end{array}$ & $\begin{array}{c}2.50 \\
-\end{array}$ \\
\hline Total & $\begin{array}{l}F \\
M\end{array}$ & 49 & $\begin{array}{r}446 \\
12\end{array}$ & $\begin{array}{l}40.59 \\
32.58\end{array}$ & $\begin{array}{l}3.97 \\
2.39\end{array}$ & 52 & $\begin{array}{r}630 \\
22\end{array}$ & $\begin{array}{l}40.67 \\
32.86\end{array}$ & $\begin{array}{l}3.81 \\
2.63\end{array}$ & 54 & $\begin{array}{r}744 \\
11\end{array}$ & $\begin{array}{l}39.37 \\
31.77\end{array}$ & $\begin{array}{l}4.04 \\
1.95\end{array}$ & 155 & $\begin{array}{r}820 \\
45\end{array}$ & $\begin{array}{l}40.12 \\
32.52\end{array}$ & $\begin{array}{l}3.99 \\
2.41\end{array}$ \\
\hline
\end{tabular}

F: Female, M: Male.

\section{Results}

\section{Size Composition in Mantle Length}

According to Table 1 , the yearly mean mantle lengths for females ranged from $39.4 \mathrm{~cm}$ to $40.7 \mathrm{~cm}$; the 3-year total mean length was $40.1 \mathrm{~cm}$, while those for males ran from $31.8 \mathrm{~cm}$ to $32.9 \mathrm{~cm}$; the 3 -year total mean length was $32.5 \mathrm{~cm}$. Thus, the females were about $8 \mathrm{~cm}$ larger than the males in total mean length.

On the other hand, the monthly mean mantle lengths in females ranged from $36.7 \mathrm{~cm}$ to $42.8 \mathrm{~cm}$, while those in males ran from $30.1 \mathrm{~cm}$ to $35.5 \mathrm{~cm}$. The largest females occurred during the first half of the fishing season, from June through September, while the largest standard values of deviation for the females occurred in September-October.

According to the length-frequency distributions, by size class at $1 \mathrm{~cm}$ intervals, shown in Fig. 2 , the range of mantle lengths of females $(26-51 \mathrm{~cm})$ was much wider than that of males $(26-37 \mathrm{~cm})$. In 1983 and 1984, the principal modal length in females shifted from $37 \mathrm{~cm}$ level in June to $45 \mathrm{~cm}$ level in September, then backed again to a smaller modal size within the range of $35-41 \mathrm{~cm}$ level in October and November (Fig. 2-1, 2). In 1985, however, the modal length shifted from the higher level of $37-44 \mathrm{~cm}$ in June-August to the lower level of 33-35 cm in September-October (Fig. 2-3). On the other hand, the 3-year total modal length

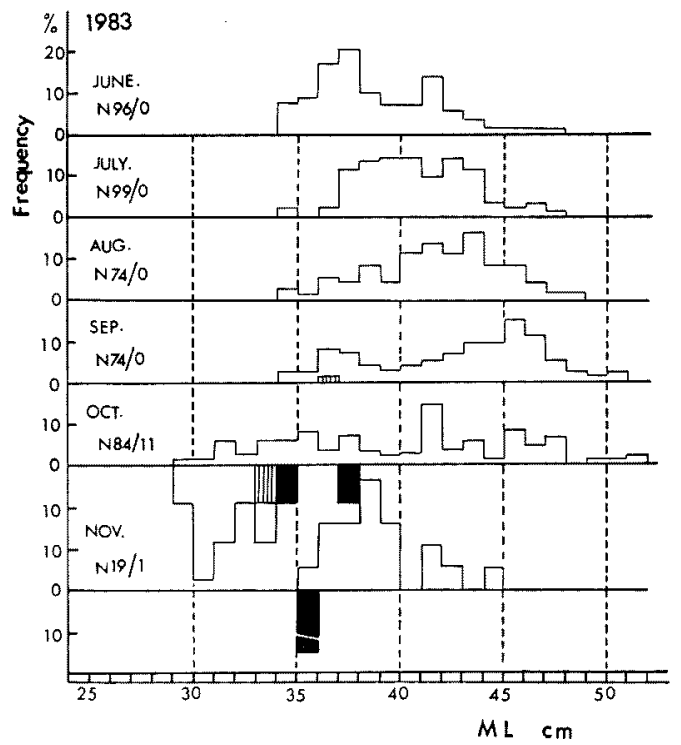

Fig. 2-1. Mantle length compositions of neon fiying squid caught by two squid gillnetters in 1983 .

Upper part of standard line: Female, Lower part: Male, N: Numbers of female/male squid measured

$\square$ immature and not copulated female, or immature male

Iini immature and coputated female, or semimature male

mature male 


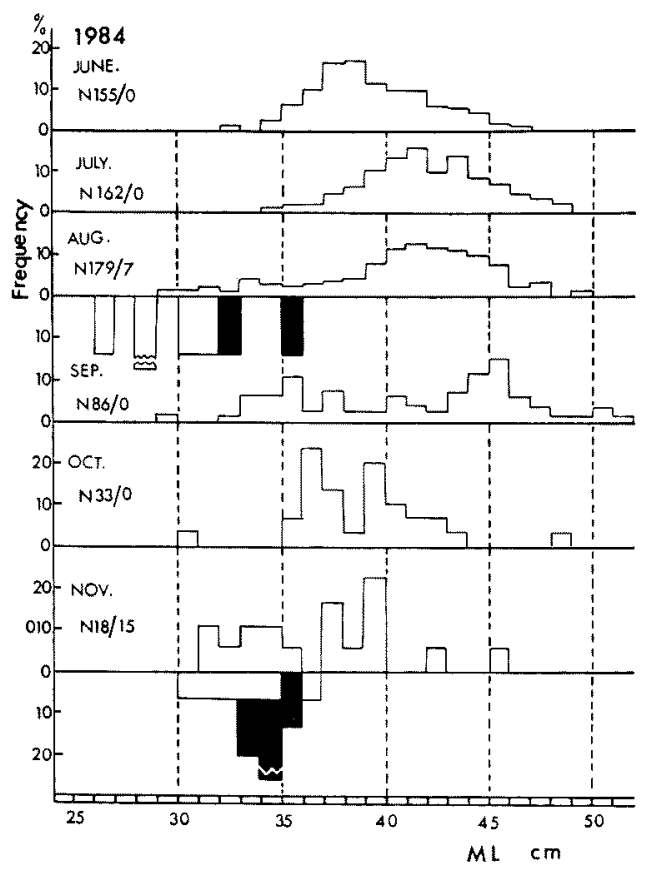

Fig. 2-2. Mantle length compositions of neon fiying squid caught by three squid gillnetters in 1984 . Legends: See Fig. 2-1

in males appeared at $30 \mathrm{~cm}$ level in SeptemberOctober and $34 \mathrm{~cm}$ level in November. However, because of the extermely small sample size, it was impossible to clearly describe the monthly variations in size of the males.

\section{Relationship between Mantle Length and Body Weight}

The coefficient of fatness for females was calculated for each size class of mantle length at $1 \mathrm{~cm}$ intervals, and shown in Fig. 3. The coefficient of fatness $(C F)$ is defined as follows:

$$
\mathrm{CF}=\mathrm{BW} \backsim 10^{3} / \mathrm{ML}^{3}
$$

where $\mathrm{BW}$ is the body weight in $\mathrm{g}$, and ML is the

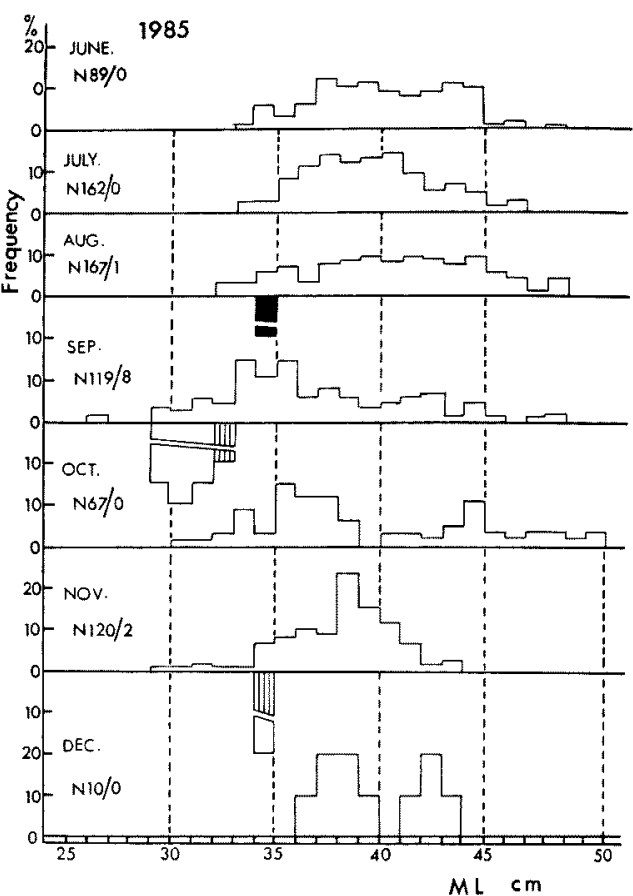

Fig. 2-3. Mantle length compositions of neon flying squid caught by three squid gillnetters in 1985.

Legends: See Fig. 2-1

mantle length in $\mathrm{cm}$. Relevant figures are not available for males because of the shortage of data.

In the case of female samples ranging from 32 to $47 \mathrm{~cm}$ in dorsal mantle length, the mean coefficient of fatness varied between 28 and 32 . The variations dependent on mantle length as well as on time (year) were quite considerable. However, in 1983 and 1985, the mean coefficient of fatness tended to increase as the mantle length increased (Fig. 3).

In Fig. $4, L_{1}$ represents the relationship between mantle length and body weight in females. The body weights used here were the 3-year average

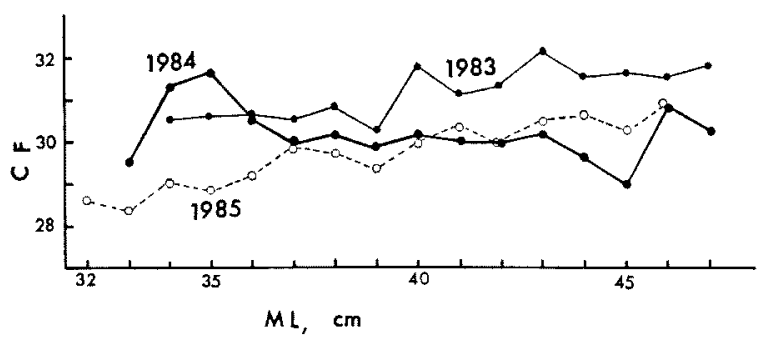

Fig. 3. Relationship between mantle length (ML) and mean coefficient of fatness (CF) of female neon flying squid calculated for each size class of $M L$ at $1 \mathrm{~cm}$ in intervals. 


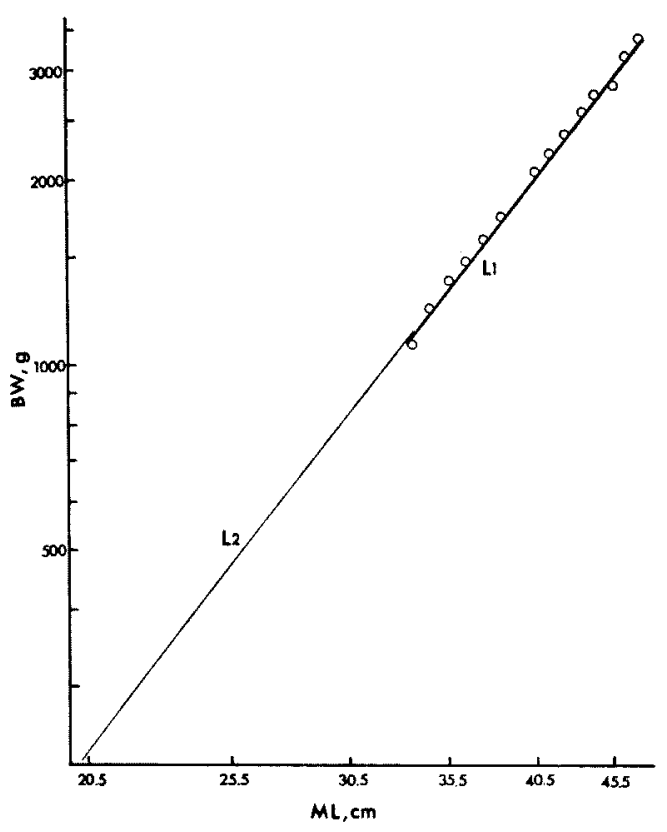

Fig. 4. Relationship between mantle length (ML) and body weight (BW) of neon flying squid.

$\mathrm{L}_{1}$ : Regression line based on samples by squid gillnetters under consideration

$L_{2}$ : Regression line based on samples by squid jiggers from the waters off the coast of the Sanriku district and Hokkaido ${ }^{2)}$

values calculated by each size class of mantle length at $1 \mathrm{~cm}$ intervals. The linear regression equation between mantle length ( $\mathrm{ML}$ in $\mathrm{cm}$ ) and body weight ( $\mathrm{BW}$ in $\mathrm{g}$ ) estimated by means of the method of least squares, was as follows:

$$
\mathrm{BW}=1.955 \mathrm{ML}^{3.1102} \times 10^{-2}
$$

Here, the coefficient of correlation was 0.999 and the mantle length ranged from $33.0 \mathrm{~cm}$ to $47.9 \mathrm{~cm}$.
On the other hand, $L_{2}$ in Fig. 4 represents the relationship between mantle length and body weight of squid, both sexes combined, caught in the waters off the Pacific coast of Japan by squid jigging vessels between June and November ${ }^{2)}$. As seen clearly in Fig. 4, both lines $L_{1}$ and $L_{2}$ are in quite well agreement each other. That is, the body weights at $20.5 \mathrm{~cm}$ and $45.5 \mathrm{~cm}$ of mantle length calculated from the two linear regression equations of $L_{1}$ and $L_{2}$ are $241 \mathrm{~g} ; 237 \mathrm{~g}$ and $2,903 \mathrm{~g} ; 2,905 \mathrm{~g}$, respectively. Thus, the following equation derived from equations of those two lines, is believed to represent the general relationship between mantle length $(20-47 \mathrm{~cm})$ and body weight of this species in the North Pacific during summer and autumn.

$$
\mathrm{BW}=1.781 \mathrm{ML}^{3.1442} \times 10^{-2}
$$

\section{Sex Ratio}

As shown in Table 1, most of the specimens were female squid. Males accounted for merely $1.5-3.4 \%$ of the total specimens in each fishing season; the 3-year average was $2.4 \%$. No males occurred in the June and July samples. On the other hand, the exceptionally large proportion of males occurred in October $1983(11.6 \%)$ and in November $1984(45.5 \%)$. One of the samples collected in October 1983, including 22 females and 11 males, and all of the samples collected in November 1984 were from the waters between long. $144^{\circ} \mathrm{E}$ and $147^{\circ} \mathrm{E}$.

\section{Sexual Maturity}

As shown in Table 2, all of the females were in the immature and not copulated condition, except for only 3 females in the immature and copulated condition. None was sexually mature. As for the 3 immature, copulated females, 1 was taken in

Table 2. Numbers of individuals measured, classed by each of stages of maturity of neon fiying

\begin{tabular}{|c|c|c|c|c|c|c|c|c|c|}
\hline \multirow{2}{*}{$\begin{array}{l}\text { Stage* of } \\
\text { Maturity }\end{array}$} & \multicolumn{5}{|c|}{ Female } & \multicolumn{4}{|c|}{ Male } \\
\hline & 1 & 2 & 3 & 4 & Total & 1 & 2 & 3 & Total \\
\hline June & 340 & 0 & 0 & 0 & 340 & 0 & 0 & 0 & 0 \\
\hline July & 423 & 0 & 0 & 0 & 423 & 0 & 0 & 0 & 0 \\
\hline Aug. & 429 & 1 & 0 & 0 & 430 & 3 & 2 & 3 & 8 \\
\hline Sep. & 277 & 2 & 0 & 0 & 279 & 7 & 1 & 0 & 8 \\
\hline Oct. & 181 & 0 & 0 & 0 & 181 & 8 & 1 & 2 & 11 \\
\hline Nov. & 157 & 0 & 0 & 0 & 157 & 6 & 1 & 11 & 18 \\
\hline Dec. & 10 & 0 & 0 & 0 & 10 & 0 & 0 & 0 & 0 \\
\hline Total & 1,817 & 3 & 0 & 0 & 1,820 & 24 & 5 & 16 & 45 \\
\hline
\end{tabular}
squid caught by gillnetters in 1983-1985

- 1: Immature and not copulated female, or immature male, 2: Immature and copulated female, or semi-mature male, 3: Mature and not copulated female, or mature male, $4:$ Mature and copulated female. 
August ( $30 \mathrm{~cm}$ in mantle length), and 2 were taken in September $(36 \mathrm{~cm}$ and $39 \mathrm{~cm}$ ). Some $15-24$ spermatozoa sacs were found adhering to the buccal membrane of these 3 copulated females.

On the other hand, as for a total of 45 males sampled, $24(53.3 \%)$ were immature, while 5 $(11.1 \%)$ were semi-mature and $16(35.6 \%)$ were mature. The semi-mature males ranged from $30 \mathrm{~cm}$ to $34 \mathrm{~cm}$ in mantle length, while the mature males were between $31 \mathrm{~cm}$ and $37 \mathrm{~cm}$ with a modal length of $35 \mathrm{~cm}$ level. Ten mature males taken in November were from the waters between long. $144^{\circ} \mathrm{E}$ and $152^{\circ} \mathrm{E}$.

The ovary weights showed a general tendency to gradually increase between June and August. However, this was followed by an abrupt decrease in September (Fig. 5). Furthermore, there were extremely few females with ovary weights of more than $30 \mathrm{~g}$ every year: merely $1.4 \%$ in $1983,0.5 \%$ in 1984 , and $0.4 \%$ in 1985 .

In Fig. 6 is shown the relationship between ovary weight and mantle length in 1984 . The gonad index (GI), represented by the solid curves in this figure, is defined as follows:

$$
\mathrm{GI}=\mathrm{OW} \times 10^{5} / \mathrm{ML}^{3}
$$

where OW is the ovary weight in $g$ and $M L$ is the mantle length in $\mathrm{cm}$.

Judging from the relationships between ovary weight and mantle length during the 3 years of 1983-1985, individuals with gonad index between 10 and 30 predominated in each month between June and November. Any increase in gonad index with time was not recognizable in the data. On the contrary, there was a clear decrease in the proportion of females with gonad index greater than 20 from June-August $(20-62 \%$, average $36 \%$ to September-October $(7-40 \%$, average $19 \%$. Females with gonad index greater than 40 were extremely few; only 2 in June with GI's of 49 and 63,3 in August with GI's of 47,50 and 51 and 3 in September with GI's of 40, 65 and 69 in the 3 years of sampling. The ovary weight and gonad index of the immature, copulated females were $10.3 \mathrm{~g}$ and 20.5 in an individual sampled in September 1983, and $4.9 \mathrm{~g}$ and 16.8 in an individual sampled in August 1984.

On the other hand, Fig. 7 shows the relationship between mantle length and testis weight in males. Although testis weights ranged widely between $4 \mathrm{~g}$ and $35 \mathrm{~g}$, and some $83 \%$ of them were confined to a narrower range from $10 \mathrm{~g}$ to $28 \mathrm{~g}$. The gonad index (GI), represented by the solid curves in Fig. 7 , is defined as follows:

$$
\mathrm{GI}=\mathrm{TW} \times 10^{5} / \mathrm{ML}^{3}
$$

where TW is the testis weight in $\mathrm{g}$ and $\mathrm{ML}$ is the mantle length in $\mathrm{cm}$.

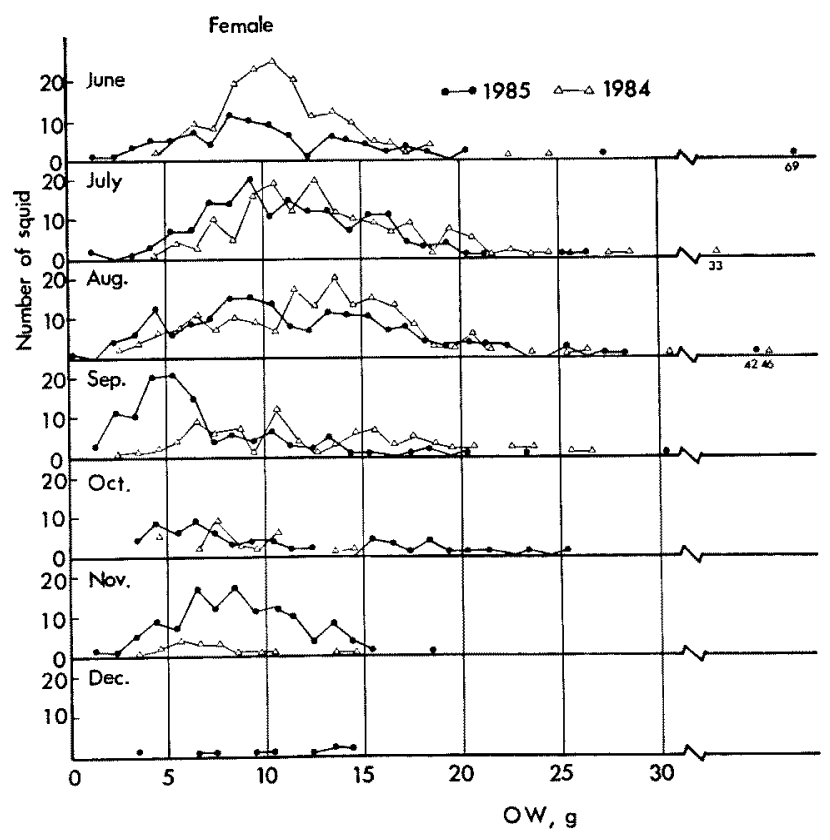

Fig. 5. Ovary weight (OW) compositions of neon flying squid caught by squid gillnetters in 1984 and 1985 . 


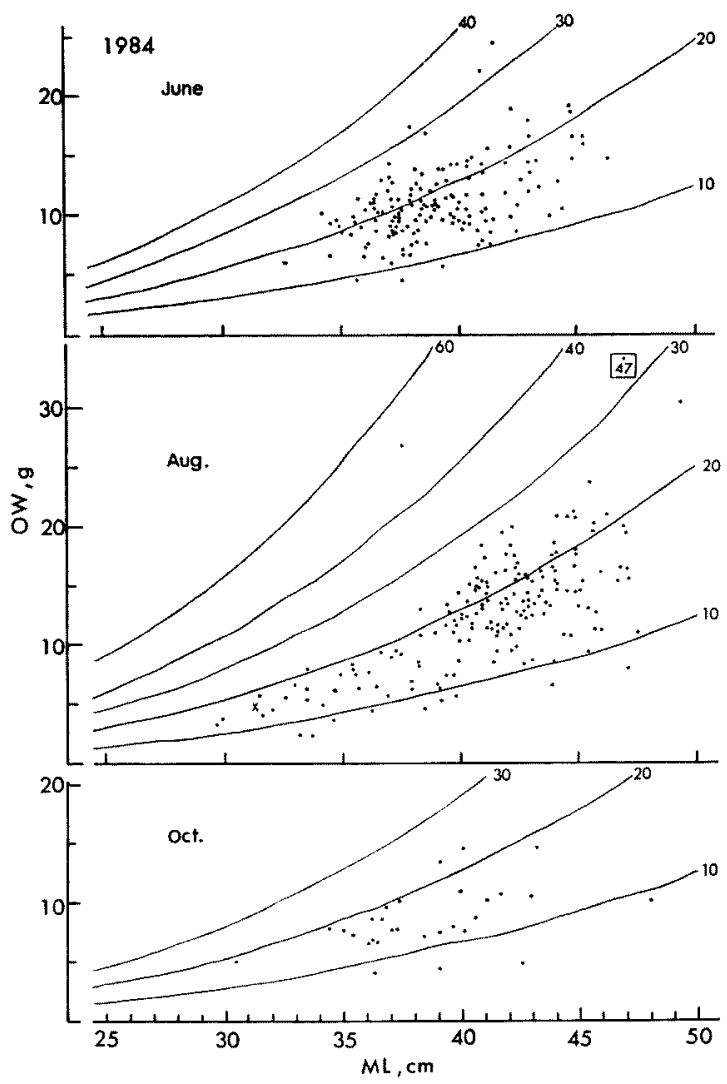

Fig. 6. Relationship between mantle length (ML) and ovary weight (OW) of female neon flying squid caught by squid gillnetters in 1984. Solid lines and numerals (10-60) indicate gonad index calculated theoretically.
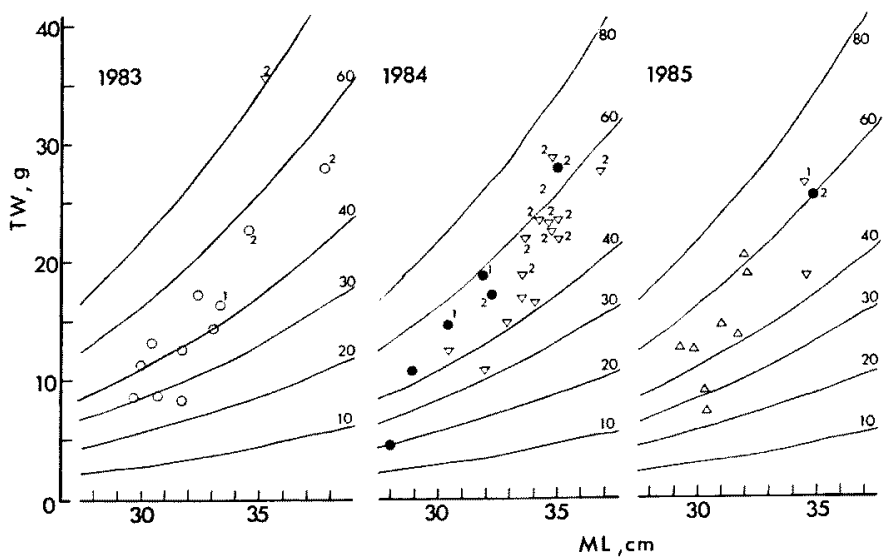

Fig. 7. Relationships between mantle length (ML) and testis weight (TW) of male neon flying squid caught by squid gillnetters in 1983-1985. Solid lines and numerals (10-80) indicate gonad index calculated theoretically.

- Aug., $\triangle$ Sep., $O$ Oct., $\nabla$ Nov.

1: Semi-mature, 2: Mature, (Circles with no numerals): Immature 
The gonad indices ranged between 20 and 70 , with most falling between 40 and 60 . As in the case of females, no increases in gonad index with time were discernible in the males. The testis weight of the semi-mature males ranged between $14 \mathrm{~g}$ and $26 \mathrm{~g}$ (average $18.9 \mathrm{~g}$ ), while the gonad indices fell between 45 and 64 (average 55.3). In the case of the mature males, the range of tests weight was from $16 \mathrm{~g}$ to $36 \mathrm{~g}$ (average $24.5 \mathrm{~g}$ ), while the gonad indices were from 51 to 81 (average 58.0).

\section{Discussion}

The neon flying squid stock which occurs in the northern North Pacific during summer and autumn is reported to consist of four size groups as follows: LL or "extra-large sized," $L$ or "large sized," $S$ or "small sized" and SS or "extra-small sized" groups. $\left.{ }^{4}{ }^{5}\right)$ Accordingly, the monthly samples of female neon flying squid in this study were separated into the respective size groups, as shown in Fig. 8. The group separation was based on the range of mantle lengths, according to the growth pattern observed by Murata et al. ${ }^{5)}$ Moreover, the size-group composition during the entire fishing season was derived from the monthly catches in number, estimated from the average body weights and catches.

According to Fig. 8, the LL size group was predominant in the June-August samples (89$100 \%$ ), but declined rather markedly in SeptemberOctober to $20-76 \%$, and more sharply to less than $5 \%$ in November and December. On the other hand, the $\mathrm{L}$ group, which was extremely few in June-August, increased abruptly to $24-69 \%$ in September, and became the dominant group (42$95 \%$ ) in October-December. The $\mathrm{S}$ group was virtually non-existent between June and October, but increased slightly in November-December. The SS group was totally absent in the samples. During the entire fishing season, the LL group was the most abundant $(63-82 \%)$, followed by the $\mathrm{L}$ group (16-33\%) and finally by the $\mathrm{S}$ group $(2-6 \%$. Furthermore, during the 3 years from 1983 to 1985 , a tendency was seen for the LL group to decrease and the $\mathrm{L}$ group to increase.

It is previouly reported ${ }^{2-4)}$ that males attain sexual maturity earlier than females in neon flying squid; at sexual maturity, the mantle lengths of males are around $30-32 \mathrm{~cm}$, and the gonad weights are approximately $15-20 \mathrm{~g}$. In contrast, the mantle lengths and gonad weights in females at

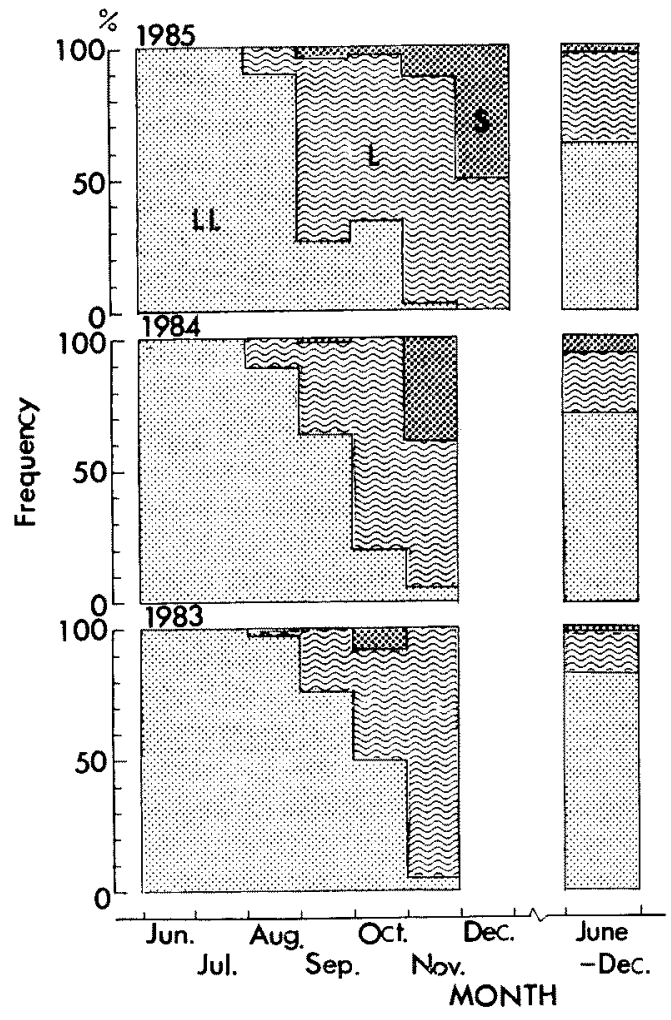

Fig. 8. Monthly changes in frequency distributions of three size groups of neon flying squid in number caught by squid gillnetters in 1983-1985.

$\$$ LL group (dorsal mantle length: $30 \mathrm{~cm}$ or more in June and July, $35 \mathrm{~cm}$ or more in Aug., $39 \mathrm{~cm}$ or more in Sep., $41 \mathrm{~cm}$ or more in Oct., $43 \mathrm{~cm}$ or more in Nov.)

圈 L group $(28-34 \mathrm{~cm}$ in Aug., $30-38 \mathrm{~cm}$ in Sep., $32-40 \mathrm{~cm}$ in Oct., $35-42 \mathrm{~cm}$ in Nov., 39 or more in Dec.)

S group (29 cm or less in Sep., $31 \mathrm{~cm}$ or less in Oct., $34 \mathrm{~cm}$ or less in Nov., $38 \mathrm{~cm}$ or less in Dec.)

sexual maturity are approximately $38-42 \mathrm{~cm}$ and $50-60 \mathrm{~g}$, respectively. Moreover, Suzuki ${ }^{8)}$ reported the gonad indices in mature males (based on 5 specimens) and in mature, copulated females (4 specimens) as 21-59 and 54-171, respectively.

Judging from these reports, as well as from the results of the present study, it appears that all of the immature, as well as semi-mature males in our samples are close to attaining the mature stage. On the other hand, with the exception of the very small numbers of females with gonad weights exceeding $30 \mathrm{~g}$, it appears that a considerable time is yet required for females to reach the 
mature stage. However, since many of the females that were thought to be in the LL group, were larger than $40 \mathrm{~cm}$ in mantle length after August, it is expected that these will rapidly advance toward the mature stage.

Judging from the results ${ }^{7-10) * 1, * 2}$ of recent surveys with gillnets of varying mesh sizes in the North Pacific, neon fiying squid occurring in the summer in waters east of long. $170^{\circ} \mathrm{E}$ showed a tendency for larger individuals to be distributed farther to the north than the samller ones. It has also been reported ${ }^{* 1, * 2}$ that there was a higher proportion of females toward the north, while the sex ratio was either about equal or slightly in favor of males farther to the south.

Based on such information, as well as from the consideration of the sizes and sex ratios of squid taken in the present study, it is considered that the squid gillnetters catch selectively the larger females which migrate northward in advance of the others. In other words, the gillnetters catch mainly the LL group of squid in June-August, the LL and $\mathrm{L}$ groups in September-October, and the $L$ group in November-December. Also, judging from the discontinuous variation in size and ovary weight distributions at around SeptemberOctober, it is postulated that the main objects of the fishery in June-August will gradually begin shifting southward, beginning with the more sexually advanced individuals, and that by around October, most of them will have reached the spawning area which is located to the south of the fishing grounds.

The possibility is suggested of rather large differences in mantle length of squid in the gillnet catches, not only between areas, but also between vessels, even among catches taken during the same period (Murata, unpublished). Furthermore, large amounts of information have recently been obtained regarding the distribution and migration of squid belonging to the four different size groups. $\left.{ }^{4,5}, 9,10\right) * 1, * 2$ However, many unanswered questions still remain pertaining to the interrelaships between those groups, as well as on their reproductive potentials.

\section{Acknowledgements}

We wish to thank Dr. T. Otsu in Honolulu, and Dr. T. Sato, Hokkaido Regional Fisheries Research Laboratory, Kushiro, for reading the manuscript with suggetions for its improvement.

\section{References}

1) M. Murata and Y. Nakamura: Suisan Sekai, 36(5), $44-49$ (1987) (in Japanese).

2) M. Murata and M. Ishii: Bull. Hokkaido Reg. Fish. Res. Lab., 42, 1-24 (1977).

3) S. Kubota, M. Akabane, K. Takanashi, T. Hashiba, and T. Suzuki: Bull. Tohoku Reg. Fish. Res. Lab., 41, 111-116 (1979).

4) K. Murakami, Y. Watanabe, and J. Nakata: in "Pelagic Animmals and Environments around the Subarctic Boundary in North Pacific" (ed. by S. Mishima), Res. Inst. North Pac. Fish. Hokkaido Univ., Spe. Vol., 161-179 (1981).

5) M. Murata, M. Ishii, and S. Kubota: Report of 1983 annual meeting on resources and fisheries of squid, Tohoku Reg. Fish. Res. Lab., Hachinohe, 1985, pp. 36-49 (in Japanese).

6) H. Suzuki: Bull. Jap. Fish. Ocean., 36, 11-18 (1980).

7) T. Fujii, N. Masuda, G. Kobayashi, G. Anma, H. Yamaguchi, and N. Kijima: Bull. Jap. Fish. Ocean., 35, 44-51 (1979) (in Japanese).

8) S. Mishima: in "Pelagic Animmals and Environments around the Subarctic Boundary in North Pacific" (ed. by S. Mishima), Res. Inst. North Pac. Fish. Hokkaido Univ., Spe. Vol. 6171 (1981).

9) T. Kubodera, W. G. Pearcy, K. Murakami, T. Kobayashi, J. Nakata, and S. Mishima: Mem. Fac. Fish. Hokkaido Univ. 30, 1-49 (1983).

10) G. Kobayashi, N. Masuda, G. Anma, T. Meguro, H. Yamaguchi, and S. Takagi: Mem. Fac. Fish. Hokkaido Univ., 37(3), 181-189 (1986).

*1 M. Murata, M. Ishii, Y. Nakamura, and C. Shingu: Report of 1984 annual meeting on resources and fisheries of squid, Hokkaido Reg. Fish. Res. Lab., 76-85 (1985) (in Japanese).

*2 M. Murata: Document submitted to the 33rd Conference of the International North Pacific Fisheries Commision, 1986, p. 17.

Nippon Suisan Gakkaishi : Formerly Bull. Japan. Soc. Sci. Fish 